Volume 5, Issue 2 (Summer 2013)

\title{
Dirck van Baburen and the "Self-Taught" Master, Angelo Caroselli
}

Wayne Franits

Recommended Citation:

Wayne Franits, "Dirck van Baburen and the "Self-Taught” Master, Angelo Caroselli” JHNA 5:2 (Summer 2013), DOI:10.5092/jhna.2013.5.2.5

Available at https://jhna.org/articles/dirck-van-baburen-self-taught-master-angelo-caroselli/

Published by Historians of Netherlandish Art: https://hnanews.org/

Republication Guidelines: https://jhna.org/republication-guidelines/

Notes: This PDF is provided for reference purposes only and may not contain all the functionality or features of the original, online publication. This is a revised PDF that may contain different page numbers from the previous version. Use electronic searching to locate passages. This PDF provides paragraph numbers as well as page numbers for citation purposes.

ISSN: 1949-9833 


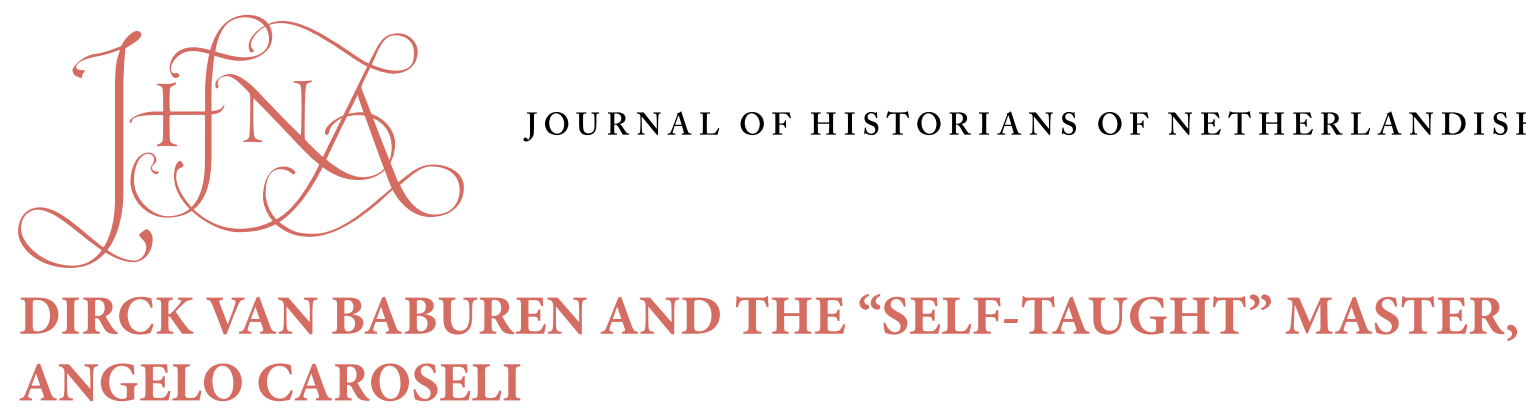

Wayne Franits

During his approximately eight-year stay in Rome, the noted Utrecht Caravaggist, Dirck van Baburen, responded to the work of some of the Eternal City's most influential painters. It has long been known, for example, that Van Baburen appropriated motifs and pictorial devices from such eminent Italian artists as Caravaggio and Bartolomeo Manfredi as well as the Spaniard, Jusepe de Ribera. The present essay argues that the art of the little-known Italian master, Angelo Caroselli, also exerted a formidable impact upon the Dutchman, particularly the latter's portrayal of genre subjects produced after his return to his native Utrecht. 10.5092/jhna.2013.5.2.5

I $\mathrm{n}$ the course of conducting research for my recent monograph on Dirck van Baburen (ca. 1592/93-1624), I became acquainted with the work of the somewhat obscure but ever-fascinating seventeenth-century Italian painter Angelo Caroselli (1585-1652). Better known today among specialists than the public, Caroselli was a native Roman who, according to his two biographers, Giovanni Battista Passeri and Filippo Baldinucci, was entirely self-taught. ${ }^{1} \mathrm{He}$ apparently possessed sufficient talent to make flawless copies of the work of the most esteemed masters, among others, Poussin and Raphael. ${ }^{2}$ Such was his reputation in this arena that even Vincenzo Giustiniani, one of the eminent Maecenases of the era, owned a tiny painting of Saint Matthew by Caroselli that "imitated" a picture by Caravaggio. ${ }^{3}$

Caroselli initially enjoyed a rather peripatetic career; thanks to the work of several scholars, his once perplexing meanderings have been clarified. ${ }^{4}$ Although he enrolled in the Academy of St. Luke in Rome in 1604, Caroselli spent time in Florence, possibly in 1605-06 or 1610 and then returned to his native city. In 1611-12, he received a contract to paint two prophets and a Pietà (fig. 1) for the ceiling of the Vittrice Chapel in Santa Maria in Vallicella (Chiesa Nuova). ${ }^{5}$ The artist remained in Rome for several years, marrying there in 1615 and assisting Giovan Francesco Guerrieri (1589-1657) in the decoration of the then newly constructed Palazzo Borghese in the Campo Marzio. ${ }^{6}$ In November of 1616, Caroselli and his wife quit Rome, perhaps spending several months in Piedimonte Matese in the province of Caserta. The couple then continued on to Naples, where they remained (along with their three children who were born there) until 1625. Thereafter, Caroselli and his young family returned to Rome for good.

3 Turning now to Dirck van Baburen, the young Dutch master most likely arrived in Italy in the summer or fall of 1612 , if not in early $1613 .^{7}$ We will probably never know what specific Italian 


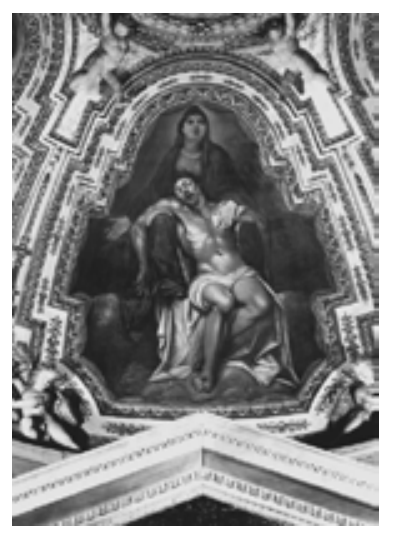

Fig. 1 Angelo Caroselli, Pietà, ca. 1611-12, oil on plaster, size unknown. Vittrice Chapel, Santa Maria in Vallicella, Rome (artwork in the public domain)

cities Van Baburen visited or whether he did so before or after he had settled in Rome, but one thing is certain: he spent most of his approximately eight-year stay in Italy in the Eternal City, where he established a solid reputation relatively quickly. ${ }^{8}$-Van Baburen's years in Rome only partly overlapped with those of Caroselli. Like sizable numbers of their fellow artists, the two resided in parishes in the northern section of the city. ${ }^{9}$ Thanks to the Stati delle Anime (registers of persons), censuses conducted annually at Easter time by Rome's parish churches, we know that until his departure in late 1616, Caroselli continued to live in the parish in which he had been born, that of Santa Maria in Lucina. ${ }^{10}$ The Stato delle Anime for the nearby parish of Sant'Andrea delle Fratte for 1619 records Van Baburen's presence and that of a fellow artist, David de Haen, in a house on the Piazza della Trinità della Monte; they were living together with a certain Cornelio Brabrandia, who was probably a painter too. ${ }^{11}$ The following spring, in what would be Van Baburen's last year in Italy, 1620, the Stato delle Anime for Sant'Andrea delle Fratte once again listed him and De Haen, who were now lodging with the French painter Nicolas Régnier (ca. 1588-1667), a servant, and an apprentice, "Giovan Antonio Piemontese."12

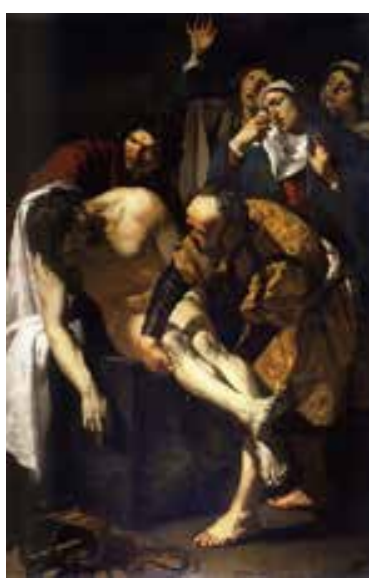

Fig. 2 Dirck van Baburen, The Entombment, 1617 , oil on canvas, $222 \times 142 \mathrm{~cm}$. Pietà Chapel, San Pietro in Montorio, Rome (artwork in the public domain)

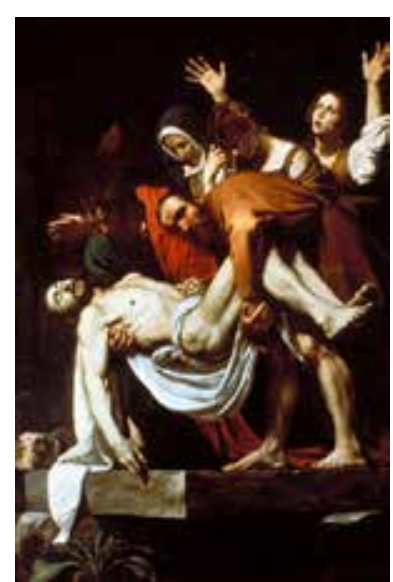

Fig. 3 Caravaggio, The Entombment, ca. 1601-04, oil on canvas, $300 \times 203 \mathrm{~cm}$. Vatican Museums, Rome, inv. no. 40386 (artwork in the public domain)

Unfortunately, we lack documentation for Van Baburen's living arrangements prior to 1619. All the same, given the proximity of their respective parishes, their shared profession, and the fairly tight networks of painters and patrons in early seventeenth-century Rome, it is plausible to hy- 
pothesize that Caroselli and Van Baburen knew one another. Regardless, Van Baburen was most certainly familiar with Caroselli's work. Consider, for example, the Dutch painter's famed altarpiece The Entombment (fig. 2), painted in 1617 as part of a group of canvases made for a Spanish patron to adorn the Pietà Chapel in the church of San Pietro in Montorio, perched high on the Janiculum Hill in western Rome. ${ }^{13}$ It is well known that The Entombment testifies to its maker's knowledge of the chiaroscuro effects and volumetric forms of Caravaggio's famous painting of the same subject (fig. 3), which hung at that time in the Vittrice Chapel in Santa Maria in Vallicella.

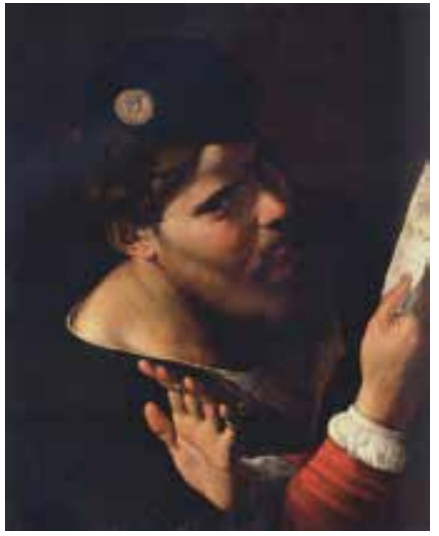

Fig. 4 Angelo Caroselli, Man Singing, ca. 1612-16, oil on panel, $53 \times 43 \mathrm{~cm}$. Kunsthistorisches Museum, Vienna, inv. no. 1583 (artwork in the public domain)

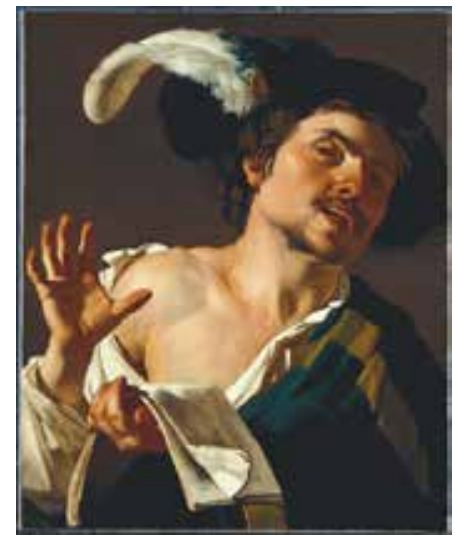

Fig. 6 Dirck van Baburen, Singing Man, 1622, oil on canvas, $71 \times 58.8 \mathrm{~cm}$. Städel Museum, Frankfurt am Main, inv. no. 2242 (artwork in the public domain)

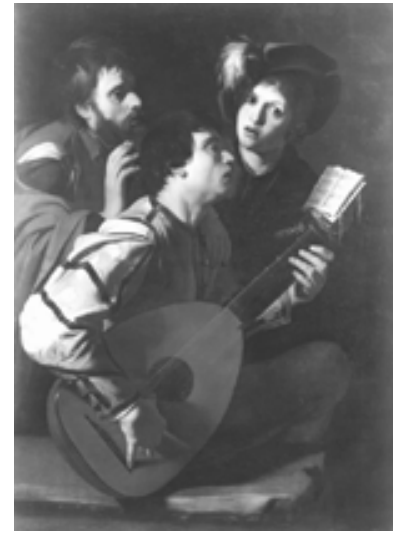

Fig. 5 Bartolomeo Manfredi, The Concert, ca. 1610-12, oil on canvas, $135.5 \times 97.3 \mathrm{~cm}$. Private Collection (artwork in the public domain)

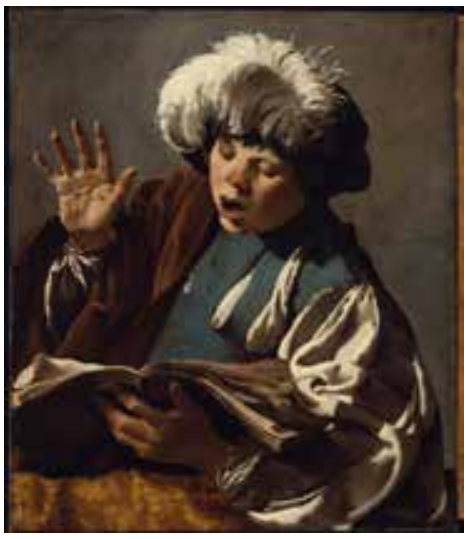

Fig. 7 Hendrick ter Brugghen, Singing Boy, 1627 , oil on canvas, $85.5 \times 71.5 \mathrm{~cm}$. Boston Museum of Fine Arts, inv. no. 58.975 (artwork in the public domain)

Van Baburen's exposure to Caravaggio's work must have impressed upon him the fact that strongly illuminated figures set against a dark background literally stand out forcefully within a dusky chapel. Van Baburen also deployed the same basic compositional structure as Caravaggio, with its wedgelike arrangement of figures set at a diagonal, cascading downward toward the body of the dead Christ. In Van Baburen's Entombment, however, the stone of the tomb, which, like the Italian's, also serves as the stone of unction (with its eucharistic implications), is more tablelike while the body of Christ has been rendered in an upright, almost seated position. It is likely that Van Baburen appropriated this unusual motif from Caroselli. As we noted above, Caroselli had 
adorned the ceiling of the chapel directly above Caravaggio's work with paintings portraying two prophets and a Pietà. His Pietà shows Christ in a similar position (fig. 1). ${ }^{14}$

The poses of Van Baburen's and Caroselli's figures of the dead Christ exhibit distinct affinities that hardly seem coincidental. All the same, one finds even more striking parallels between the two artists' genre paintings. Caroselli's singular pictures of this sort, striking for their vivacity and, at times, their vulgarity, owe much to the work of the Ostianese painter Bartolomeo Manfredi (1582-1622), who resettled in Rome around 1600. ${ }^{15}$ Manfredi soon embarked upon a hugely successful career as an interpreter of Caravaggio's idiom, especially for a younger generation of mostly foreign painters. In essence, Manfredi successfully adopted specific stylistic and thematic devices from Caravaggio's art and, in the process, created new pictorial paradigms that proved highly influential. ${ }^{16}$ Consider, for example, Caroselli's Man Singing (fig. 4). ${ }^{17}$ While singers and related musical performers can be found in the work of Caravaggio, Manfredi's interpretation of this theme (fig. 5), employing half- to three-quarter-length figures in unarticulated, restrictive rectangular spaces, infused with rich coloration gently modulated by chiaroscuro, must have resonated resoundingly with Caroselli. As several scholars have noted, Caroselli's Singing Man evidences similar qualities. ${ }^{18}$ Yet, the close-up, oblique view of the performer as well as his homely face distance him from the more elegant figures that routinely inhabit Manfredi's prototypes.

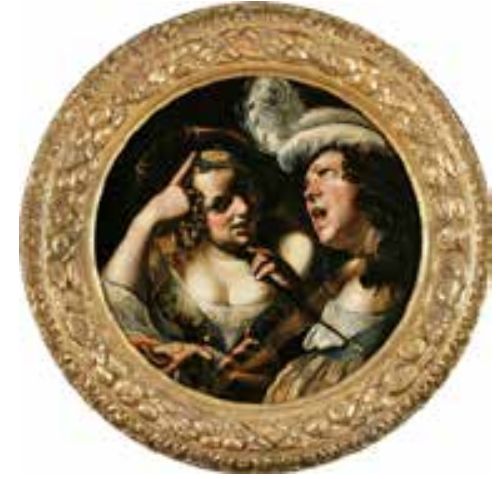

Fig. 8 Andrea Caroselli, Violinist and Courtesan, ca. $1612-16$, oil on slate, diameter $33 \mathrm{~cm}$. Otto Naumann, Ltd., New York (artwork in the public domain)

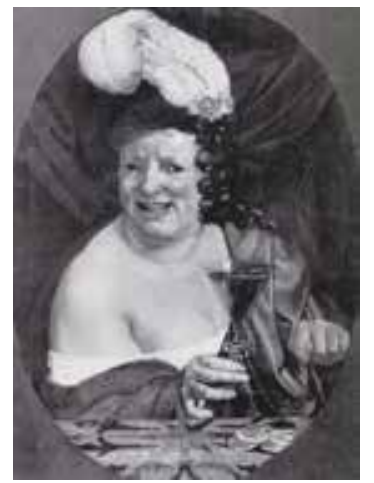

Fig. 9 Andrea Caroselli, Courtesan Making an Obscene Gesture, ca. 1612-16, oil on canvas 57 $x 50 \mathrm{~cm}$. Lemme Collection, Rome (artwork in the public domain)

It is precisely these earthy features of Caroselli's work and the very subjects themselves that appear to have made an indelible impression upon Van Baburen, although one that would not manifest itself until the latter painter had returned to Utrecht. Van Baburen's own Singing Man of 1622 (fig. 6) is, on some levels, unexplainable without Caroselli 's prototype. ${ }^{19}$ Both artists portray performers in angled poses holding musical scores while gazing at the viewer. And in both, the costumes are fanciful; Van Baburen's performer may be dressed in a more distinctly "antique" manner than is Caroselli's, but the wonderful medallion pinned to the men's hats appears in both, even if the former's hat is topped with marvelous feathers. ${ }^{20}$ Much more significantly, the singer's gesture of the raised open hand, so often credited to the Utrecht Caravaggists as a motif of their own devising (figs. 6, 7), likely owes its origins to Caroselli's picture. ${ }^{21}$ The few specialists who have noticed the correspondences between Caroselli's and Van Baburen's Singers find them puzzling. They assume that the better-known Dutchman must have influenced the Italian. This, in turn, has led to the awkward argument that Van Baburen's painting possibly reflects lost pictures 
of the same subject that he supposedly made in Rome. ${ }^{22}$ It seems not to have occurred to anyone that perhaps the Dutch master (and his Utrecht colleagues) adopted the motif from the older Italian painter. And while there have been disagreements over the dating of Caroselli's Singer and related genre paintings (see below), there is really no reason to doubt that they were painted during his first Roman period, when he was most strongly under the spell of Manfredi. ${ }^{23}$

Caroselli also produced some memorable images of audacious prostitutes that are virtually unparalleled within the broader context of early seventeenth-century Italian art. His Violinist and Courtesan (fig. 8), for example, a tondo on slate, depicts two boisterous figures whose assertive physicality in combination with their close proximity to the picture plane imparts to them an uncannily palpable presence. ${ }^{24}$ The coarse-featured buxom prostitute holds coins in one hand, while she simultaneously points to the brooch on her hat representing Danae, her Ovidian sister who was likewise seduced by money (both literally and figuratively) ${ }^{25}$ With mouth agape, her client, sporting a fantastic costume crowned by a plumage-sprouting cap, plays his violin. The forceful palpability and vulgarity of Caroselli's spirited scene is matched by others he made of analogous subject matter (fig. 9). ${ }^{26}$ In essence, his approach in these indecorous works in pressing earthy figures into the immediate foreground and clothing them in outlandish and often suggestive attire anticipates Van Baburen's own portrayals of prostitution such as his famed Procuress (fig. 10) and his lesser known Loose Company (fig. 11), painted in Utrecht in 1622 and 1623, respectively.

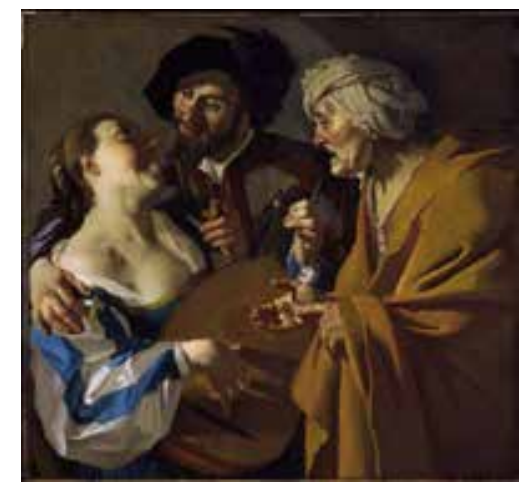

Fig. 10 Dirck van Baburen, The Procuress, 1622 , oil on canvas, $101.5 \times 107.6 \mathrm{~cm}$. Boston Museum of Fine Arts, inv. no. 50.2721 (artwork in the public domain)

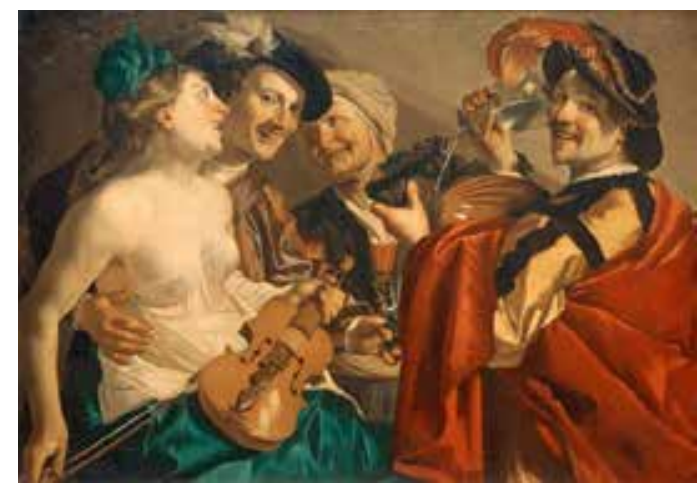

Fig. 11 Dirck van Baburen, Loose Company, 1623, oil on canvas, 108 x $153 \mathrm{~cm}$. Landesmuseum, Mainz, inv. no. 108 (artwork in the public domain)

9 None of these observations are, of course, meant to imply that Van Baburen was captivated by Caroselli's pictorial precedents to the exclusion of all else. After all, his familiarity with Northern European visual traditions, to cite just one example, is well known. Rather, within the greater ambit of Caravaggesque painting, Caroselli seems to have provided the younger painter with the most pertinent thematic and stylistic paradigms for certain subjects he would portray upon his return to his native country. Manfredi and for that matter, the Spaniard, Jusepe de Ribera (1591-1652), ${ }^{27}$ in their capacity as innovative interpreters of Caravaggio's idiom, were undeniably critical for Van Baburen's development, but his ongoing dialogue with contemporary painting in Rome inevitably led him to appropriate motifs, stylistic devices, and so forth from the work of other more "minor" masters such as Caroselli. 


\section{Acknowledgements}

I am often surprised by how my years as a student spent under the tutelage of Egbert Haverkamp-Begemann continue to inform my work three decades after the fact. As a budding young scholar of Dutch art during the 1980s, I was swayed, like so many members of my generation, by iconological methods of interpretation and hence selected a dissertation topic-domestic virtue in seventeenth-century Dutch painting - that would afford opportunities to delve rather heavily into the cultural ambient wherein such images were created. This type of research continued to fascinate me for a sustained period of time..$^{28}$ In recent years, however, I have become increasingly preoccupied with the so-called Utrecht Caravaggists in an ongoing effort to assess and catalogue genuine pictures by two of the three most prominent members of that so-called school: Hendrick ter Brugghen and Dirck van Baburen. In this regard, Egbert's invaluable instruction and wise counsel, imparted so many years ago, happily left an indelible impression upon me. I remain forever grateful that he taught his students how to examine works of art closely, and with great patience, helped us to sharpen our "eyes" and hone our skills. Little did I know way back then that those lessons would eventually prove pivotal to my future research agenda. It is therefore with gratitude and, as a way of saying "thank you," that I offer this modest contribution to him.

Wayne Franits received his Ph.D. at the Institute of Fine Arts, New York University, in 1987, under the tutelage of Egbert Haverkamp-Begemann. Currently, professor of art history at Syracuse University, he has published widely on seventeenth-century Dutch painting.

\section{List of Illustrations}

Fig. 1 Angelo Caroselli, Pietà, ca. 1611-12, oil on plaster, size unknown. Vittrice Chapel, Santa Maria in Vallicella, Rome (artwork in the public domain)

Fig. 2 Dirck van Baburen, The Entombment, 1617, oil on canvas, 222 x $142 \mathrm{~cm}$. Pietà Chapel, San Pietro in Montorio, Rome (artwork in the public domain)

Fig. 3 Caravaggio, The Entombment, ca. 1601-04, oil on canvas, 300 x $203 \mathrm{~cm}$. Vatican Museums, Rome, inv. no. 40386 (artwork in the public domain)

Fig. 4 Angelo Caroselli, Man Singing, ca. 1612-16, oil on panel, 53 x $43 \mathrm{~cm}$. Kunsthistorisches Museum, Vienna, inv. no. 1583 (artwork in the public domain)

Fig. 5 Bartolomeo Manfredi, The Concert, ca. 1610-12, oil on canvas, 135.5 x $97.3 \mathrm{~cm}$. Private Collection (artwork in the public domain)

Fig. 6 Dirck van Baburen, Singing Man, 1622, oil on canvas, 71 x $58.8 \mathrm{~cm}$. Städel Museum, Frankfurt am Main, inv. no. 2242 (artwork in the public domain) 
Fig. 7 Hendrick ter Brugghen, Singing Boy, 1627, oil on canvas, 85.5 x $71.5 \mathrm{~cm}$. Boston Museum of Fine Arts, inv. no. 58.975 (artwork in the public domain)

Fig. 8 Andrea Caroselli, Violinist and Courtesan, ca. $1612-16$, oil on slate, diameter $33 \mathrm{~cm}$. Otto Naumann, Ltd., New York (artwork in the public domain)

Fig. 9 Andrea Caroselli, Courtesan Making an Obscene Gesture, ca. 1612-16, oil on canvas 57 x $50 \mathrm{~cm}$. Lemme Collection, Rome (artwork in the public domain)

Fig. 10 Dirck van Baburen, The Procuress, 1622, oil on canvas, 101.5 x $107.6 \mathrm{~cm}$. Boston Museum of Fine Arts, inv. no. 50.2721 (artwork in the public domain)

Fig. 11 Dirck van Baburen, Loose Company, 1623, oil on canvas, 108 x $153 \mathrm{~cm}$. Landesmuseum, Mainz, inv. no. 108 (artwork in the public domain)

${ }^{1}$ Filippo Baldinucci, Notizie dei professori del disegno da Cimabue in qua . . (1681-1728; repr., Florence: Eurografica, 1974), 3:740-41; Giovanni Battista Passeri, Vite de pittori, scultori ed architetti che hanno lavorato in Roma, morti dal 1641 fino al 1673 (Rome: G. Settari, 1772), 188-89. ${ }^{2}$ The ability to create copies of other artists' work that are faithful enough to the original to deceive viewers is a leitmotif in artists' biographies. One finds, for example, the very same abilities praised in such contemporary Dutch artists as Adriaen van der Werff; see Barbara Gaehtgens, Adriaen van der Werff 1659-1722 (Munich: Deutscher Kunstverlag, 1987), 433. This aspect of inherent artistic talent is not addressed in the classic study by Ernst Kris and Otto Kurz, Legend, Myth, and Magic in the Image of the Artist, trans. Alastair Lang (London and New Haven: Yale University Press, 1979).

${ }^{3}$ Silvia Danesi Squarzina, La collezione Giustiniani (Turin: G. Einaudi, 2003), 1:455, no. 233 ("Un quadretto piccolo di S. Matteo in tavola alt. pal. 2 1/2 lar. I 1/2 di mano di Angelo Ca-roselli ad imitation del Caravaggio"). Squarzina does not believe that this copy and others in the collection were acquired as surrogates for famous paintings but rather that they should be considered the result of didactic exercises for young artists who worked under Giustiniani's auspices. Giustiniani owned additional paintings by Caroselli, a Prodigal Son and a Pygmalion and Galatea; see, respectively, La collezione Giustiniani, 1:299--300, no. 99 and 1:300-301, no. 101. Caroselli's practice of copying works of art for profit, both those from older periods as well as contemporary ones, reflects the financial significance accorded to this enterprise in early modern Europe, perhaps nowhere more so than in the oft-times shady and duplicitous art world of early seventeenth-century Rome. For the complicated status of autograph replicas and copies of original paintings in seventeenth-century Italy, see, among others, Richard Spear, "What Is An Original?" in The Italians in Australia. Studies in Renaissance and Baroque Art, ed. David R. Marshall (Florence: Centro Di, 2004), 15-32; and Luigi Spezzaferro, "Caravaggio accettato: Dal rifiuto al mercato," in Caravaggio nel iv centenario della Capalla Contarelli, ed. Caterina Volpi (Rome: CAM, 2002), 23-25.

${ }^{4}$ See especially, Carlo Stefano Salerno, "Precisazioni su Angelo Caroselli," Storia dell'Arte 76 
(1992): 346-61; Marta Rossetti, "Note sul soggiorno napoletano di Angelo Caroselli (1585-1652), appunti sulla parentesi fiorentina e alcune opere inedite," L'Acropoli: Rivista bimestrale diretta da Giuseppe Galasso 11, no. 5 (2010): 530-59. A chronological table of Caroselli's vitae and travels can be found in Daniela Semprebene, Angelo Caroselli 1585-1652: Un pittore irriverente (Rome: Gangemi Editore, 2011), 54-57; see also, 72-82, a section consisting of archival documents.

${ }^{5}$ These are oil-on-plaster paintings, which accounts for their poor condition today; see Semprebene, Angelo Caroselli, 18-19. For a color photograph of the painting and a brief discussion of it, see Francesca Cappelletti, "Angelo Caroselli (Roma 1585-1652)," in I Caravaggeschi: Percorsi e protagonisti, ed. Alessandro Zuccari (Milan: Skira, 2010), 2:346, fig. 1.

${ }^{6}$ See Semprebene, Angelo Caroselli, 21-22.

${ }^{7}$ A reassessment of the archival documents concerning Van Baburen and his family, as well as of the comments written by the Italian physician and aesthete Giulio Mancini, has led me to conclude that the artist was not born around 1595, as is customarily claimed, but two or three years earlier, that is, ca.1592/93; see Wayne Franits, The Paintings of Dirck van Baburen ca. 1592/931624: Catalogue Raisonné (Amsterdam and Philadelphia: John Benjamins Publishing Company, 2013), 2-4. Therefore, when Van Baburen departed for Rome in roughly 1612-13, he was a slightly older, more mature artist than Leonard J. Slatkes, the author of the first monograph on the painter, believed; see Leonard J. Slatkes, Dirck van Baburen (c. 1595 - 1624): A Dutch Painter in Utrecht and Rome (Utrecht: Haentjes, Dekker \& Gumbert, 1965), 1-2.

${ }^{8}$ Slatkes, Dirck van Baburen, 28, plausibly suggests that Van Baburen stopped in Venice as well as in Bologna. We also know for a fact that the artist spent at least some time in Parma. In the mid-1980s, Carel van Tuyll discovered a reference in a late eighteenth-century manuscript to an altarpiece, The Martyrdom of Saint Sebastian, which he painted for the church of Santa Maria dei Servi in that city in 1615; see also Franits, Dirck van Baburen, 238, cat. L7.

${ }^{9}$ Didier Bodart, Les peintres des Pays-Bas Méridionaux et de la Principauté de Liège à Rome au XVIIème siècle (Brussels and Rome: Institut historique belge de Rome, 1970), 1:106, points out that the papacy had provided tax exemptions to the inhabitants of several streets in this area as a way of encouraging artists and artisans to move there. For the history and development of parishes especially during the Counter-Reformation, see Claudio Schiavoni, "The Parochial System in Early Modern Rome," in Rome - Amsterdam: Two Growing Cities in Seventeenth-Century Europe, ed. Peter van Kessel and Elisja Schulte (Amsterdam: Amsterdam University Press, 1997), 24-32. ${ }^{10}$ For the parish of San Lorenzo in Lucina and the multinational artists in residence there, see Emanuela Zicarelli, "Demografia artistica: Ricerche negli stati delle anime. 2. Per un censimento degli artisti nella parrochia di San Lorenzo in Lucina," in Arte e immagine del papato Borghese (1605-1621), ed. Bruno Toscano (San Casciano: Libro Co. Italia, 2005), 33-48.

${ }^{11}$ Sonia Amadio, "Demografia artistica: Ricerche negli stati delle anime. 1. Artisti famosi e nomi senza opere nella parrochia di Sant'Andrea delle Fratte," in Arte e immagine, 17-31. The author counts 125 painters of varying nationalities inhabiting the parish of Sant'Andrea della Fratte between 1607 and 1613 and 1616 and 1621. For this parish, see also the classic study by G. J. Hoogewerff, Nederlandsche kunstenaars te Rome (1600-1725): Uittreksels uit de parochiale archieven (The Hague: Gedrukt ter Algemeene Landsdrukkerij, 1942), 224-25.

${ }^{12}$ The precise location where the four gentlemen lived is not declared, but it must have been on the Piazza della Trinità della Monte, where Van Baburen and De Haen had resided the previous year. Hoogewerff, Nederlandsche kunstenaars te Rome, 230, records the notary's statement "Als in het voorgaande jaar," which strongly suggests this. Régnier possibly took the place of Cornelia 
Brabrandia, who had been living with Van Baburen and De Haen in 1619. For Régnier's lodging situation with the two Dutchmen and a servant and apprentice in 1620, see Annick Lemoine, Nicolas Régnier (alias Niccolò Renieri) ca. 1588-1667: Peintre, collectionneur et marchand d'art (Paris: Arthena, 2007), 28-29, 370, who clarifies and amplifies Hoogewerff's findings.

${ }^{13}$ Van Baburen and the aforementioned David de Haen received this commission from Pietro Cussida, a wealthy Spanish aesthete from Zaragoza (Saragossa), the capitol of Aragon, who had arrived in Rome by 1602 to serve as a diplomatic agent to the papacy for Philip III (r. 1598-1621) and then, briefly, for Philip IV (r. 1621-65). For this commission, see further Franits, Dirck van Baburen, 9-16, 78-81, cat. A3; 97-99, cat. A7; 196-97, cat. R16; 235, cat. L3.

${ }^{14}$ Franits, Dirck van Baburen, 11. Slatkes, Dirck van Baburen, 24, 36, 38, sees a relationship between the "seated" Christ in Van Baburen's Entombment and a similar pose in an early painting by Rubens of the same subject (Borghese Gallery, Rome). This is certainly plausible.

${ }^{15}$ For decades, Manfredi's work and very person were shrouded in mystery--the very fact that he left no signed or dated pictures has plunged the question of his stylistic development into near continual debate. For Manfredi, see Mina Gregori, et al., Dopo Caravaggio: Bartolomeo Manfredi e la Manfrediana Methodus, exh. cat. (Cremona: Museo Civico ala Ponzone, 1987); Nicole Hartje, Bartolomeo Manfredi (1582-1622): Ein Nachfolger Caravaggios und seine europäische Wirkung; Monographie und Werkverzeichnis (Weimar: VDG Verlag and Datenbank für Geisteswissenschaften, 2004); and Rossella Vodret, "Bartolomeo Manfredi (Ostiano 1582 - Roma 1622)," in I Caravaggeschi, 2:515-27; and, more recently, Gianni Papi, Bartolomeo Manfredi (Soncino: Edizioni dei Soncino, 2013).

${ }^{16}$ By far, Hartje, Bartolomeo Manfredi, 117-60 and passim, constitutes the most thorough scholarly examination to date of Manfredi's influential method.

${ }^{17}$ For Caroselli's painting, see Wolfgang Prohaska and Gudrun Swoboda, Caravaggio und der internationale Caravaggismus (Vienna and Milan: Silvana Editoriale, 2010), 152-59, whose technical analysis reveals that at some point before 1837, its shape was altered: the original oval fir panel was attached to a square pinewood panel.

${ }^{18}$ For example, Cappelletti, “Angelo Caroselli," 345.

${ }^{19}$ For Van Baburen's painting, see Franits, Dirck van Baburen, 133-35, cat. A24.

${ }^{20}$ According to Prohaska and Swoboda, Caravaggio, 158-59, this glittering object is actually a Tiberian or Claudian Roman imperial coin. Part of this coin's inscription reads $B R A$ [D or $N]$, which the authors construe as an allusion to the Brandani family, who patronized the artist and perhaps commissioned this particular painting.

${ }^{21}$ In Caroselli's painting, the man's open-handed gesture seems to ward off the onlooker, while in Van Baburen's painting it probably identifies the man as a maat-zanger (measure singer), the one who provided the musical measure or beat. In addition to the musical concept of measure, the gesture is conceivably related to notions of temperance; see Marcus Dekiert, Musikanten in der Malerei der niederländischen Carvaggio-Nachfolge . . . (Münster: LIT Verlag, 2003), 103, 226; Leonard J. Slatkes and Wayne Franits, The Paintings of Hendrick ter Brugghen 1588-1629: Catalogue Raisonné (Amsterdam and Philadelphia: John Benjamins Publishing Company, 2007), 199, 207, 209; Franits, Dirck van Baburen, 134n7.

${ }_{22}$ Prohaska and Swoboda, Caravaggio, 158n16, cite Van Baburen's painting but wonder whether the Dutch artist had painted the subject during his Roman period and hence would have influenced Caroselli. Likewise, Marta Rossetti, "Strumenti musicali nella vita e nell'opera di Angelo Caroselli (1585-1652), pittore 'caravaggesco," in La musica al tempo di Caravaggio, ed. Stefania 
Macioce and Enrico de Pascale (Rome: Gangemi Editore, 2012), 203, cites the presumed precedence of paintings by Van Baburen and Ter Brugghen to explain the presence of this motif in Caroselli's picture. For Ter Brugghen's two paintings of singers, see Slatkes and Franits, Hendrick ter Brugghen, 207-08, cat. A85, pl. 84; 210-11, cat. A88, pl. 87.

${ }^{23}$ For this issue, see Cappelletti, "Angelo Caroselli," 345. Cappelletti also cites a document dated 1614 in which Caroselli declares that he will satisfy a debt with the payment of two paintings, one of which portrayed chess players.

${ }^{24}$ For this painting, see Semprebene, Angelo Caroselli, 177.

${ }^{25}$ For Danae as a model of questionable virtue, see Eric Jan Sluijter, "Emulating Sensual Beauty: Representations of Danaë from Gossaert to Rembrandt," Simiolus 27 (1999): 28-30, 34-35.

${ }^{26}$ For this painting, see Semprebene, Angelo Caroselli, 98, who convincingly demonstrates Caroselli's authorship.

${ }^{27}$ For Ribera, who like Caroselli, seems to have exerted his greatest impact upon Van Baburen during his Roman period, see, most recently, Gianni Papi, Ribera a Roma (Soncino: Edizioni dei Soncino, 2007) and Javier Portus, et al., El joven Ribera, exh. cat. (Madrid: Museo del Prado, 2011).

${ }^{28}$ It culminated, in some respects, in my overview of Dutch genre painting that was published in 2004: Wayne Franits, Dutch Seventeenth-Century Genre Painting: Its Stylistic and Thematic Evolution (London and New Haven: Yale University Press, 2004).

\section{Bibliography}

Amadio, Sonia. "Demografia artistica: Ricerche negli stati delle anime. 1. Artisti famosi e nomi senza opere nella parrochia di Sant'Andrea delle Fratte." In Arte e immagine del papato Borghese (1605-1621), edited by Bruno Toscano 17-31. San Casciano: Libro Co. Italia, 2005.

Baldinucci, Filippo. Notizie dei professori del disegno da Cimabue in qua . . 7 vols. 1681-1728; repr., Florence: Eurografica, 1974-75.

Bodart, Didier. Les peintres des Pays-Bas Méridionaux et de la Principauté de Liège à Rome au XVIIème siècle. 2 vols. Brussels and Rome: Institut historique belge de Rome, 1970.

Dekiert, Marcus. Musikanten in der Malerei der niederländischen Carvaggio-Nachfolge ... Münster: LIT Verlag, 2003.

Franits, Wayne. Dutch Seventeenth-Century Genre Painting: Its Stylistic and Thematic Evolution. London and New Haven: Yale University Press, 2004.

Franits, Wayne. The Paintings of Dirck van Baburen ca. 1592/93-1624: Catalogue Raisonné. Amsterdam and Philadelphia: John Benjamins Publishing Company, 2013.

Gaehtgens, Barbara. Adriaen van der Werff 1659-1722. Munich: Deutscher Kunstverlag, 1987. Gregori, Mina, et al. Dopo Caravaggio: Bartolomeo Manfredi e la Manfrediana Methodus. Exh. cat. Cremona: Museo Civico ala Ponzone, 1987. 
Hartje, Nicole. Bartolomeo Manfredi (1582-1622): Ein Nachfolger Caravaggios und seine europäische Wirkung; Monographie und Werkverzeichnis. Weimar: VDG Verlag and Datenbank für Geisteswissenschaften, 2004.

Hoogewerff, G. J. Nederlandsche kunstenaars te Rome (1600-1725): Uittreksels uit de parochiale archieven. The Hague: Gedrukt ter Algemeene Landsdrukkerij, 1942.

Kris, Ernst, and Otto Kurz. Legend, Myth, and Magic in the Image of the Artist. Translated by Alastair Lang. London and New Haven: Yale University Press, 1979.

Lemoine, Annick. Nicolas Régnier (alias Niccolò Renieri) ca. 1588-1667: Peintre, collectionneur et marchand d'art. Paris: Arthena, 2007.

Papi, Gianni. Ribera a Roma. Soncino: Edizioni dei Soncino, 2007.

Papi, Gianni. Bartolomeo Manfredi. Soncino: Edizioni dei Soncino, 2013.

Passeri, Giovanni Battista. Vite de pittori, scultori ed architetti che hanno lavorato in Roma, morti dal 1641 fino al 1673. Rome: G. Settari, 1772.

Portus, Javier, et al. El joven Ribera. Exh. cat. Madrid: Museo del Prado, 2011.

Prohaska, Wolfgang, and Gudrun Swoboda. Caravaggio und der internationale Caravaggismus. Vienna and Milan: Silvana Editoriale, 2010.

Rossetti, Marta. "Note sul soggiorno napoletano di Angelo Caroselli (1585-1652); appunti sulla parentesi fiorentina e alcune opere inedite." L'Acropoli: Rivista bimestrale diretta da Giuseppe Galasso 11, no. 5 (2010): 530-59.

Rossetti, Marta. "Strumenti musicali nella vita e nell'opera di Angelo Caroselli (1585-1652), pittore 'caravaggesco." In La musica al tempo di Caravaggio, edited by Stefania Macioce and Enrico de Pascale, 201-18. Rome: Gangemi Editore, 2012.

Salerno, Carlo Stefano. “Precisazioni su Angelo Caroselli." Storia dell’Arte 76 (1992): 346-61.

Schiavoni, Claudio. "The Parochial System in Early Modern Rome." In Rome - Amsterdam: Two Growing Cities in Seventeenth-Century Europe, edited by Peter van Kessel and Elisja Schulte, 24-32. Amsterdam: Amsterdam University Press, 1997.

Semprebene, Daniela. Angelo Caroselli 1585-1652: Un pittore irriverente. Rome: Gangemi Editore, 2011.

Slatkes, Leonard J. Dirck van Baburen (c. 1595-1624): A Dutch Painter in Utrecht and Rome. Utrecht: Haentjes, Dekker \& Gumbert,1965. 
Slatkes, Leonard J., and Wayne Franits. The Paintings of Hendrick ter Brugghen 1588-1629: Catalogue Raisonné. Amsterdam and Philadelphia: John Benjamins Publishing Company, 2007.

Sluijter, Eric Jan. "Emulating Sensual Beauty: Representations of Danaë from Gossaert to Rembrandt.” Simiolus 27 (1999): 4-45.

Spear, Richard. "What Is An Original?" In The Italians in Australia: Studies in Renaissance and Baroque Art, edited by David R. Marshall, 15-32. Florence: Centro Di, 2004.

Spezzaferro, Luigi. "Caravaggio accettato: Dal rifiuto al mercato." in Caravaggio nel iv centenario della Capalla Contarelli, edited by Caterina Volpi, 23-43. Rome: CAM, 2002.

Squarzina, Silvia Danesi. La collezione Giustiniani. 3 vols. Turin: G. Einaudi, 2003.

Vodret, Rossella. “Bartolomeo Manfredi (Ostiano 1582 - Roma 1622).” In I Caravaggeschi: Percorsi e protagonisti, 2 vols., edited by Alessandro Zuccari, 2:515-27. Milan: Skira, 2010..

Zicarelli, Emanuela. "Demografia artistica: Ricerche negli stati delle anime. 2. Per un censimento degli artisti nella parrochia di San Lorenzo in Lucina." In Arte e immagine del papato Borghese (1605-1621), edited by Bruno Toscano, 33-48. San Casciano: Libro Co. Italia, 2005.

Recommended Citation:

Wayne Franits "Dirck van Baburen and the "Self-Taught" Master Angelo Caroselli," JHNA 5:2 (Summer 2013), D0I: 10.5092/ jhna.2013.5.2.5 